

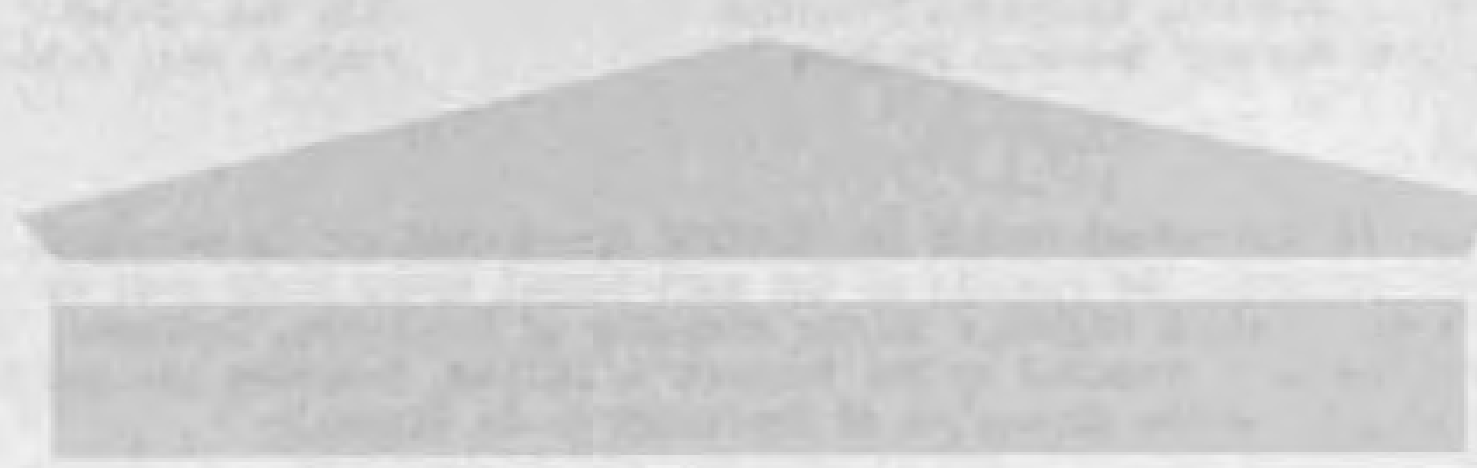

Digitized by the Internet Archive in 2011 with funding from

LYRASIS members and Sloan Foundation; Indiana Department of Transportation

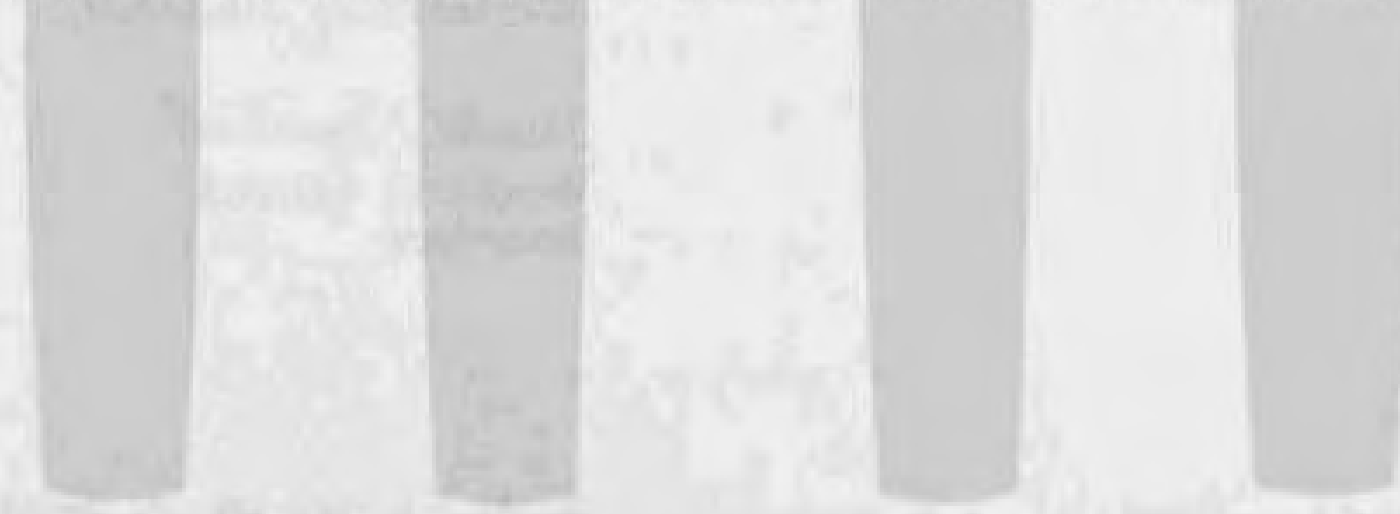

http://www.archive.org/details/trafficspeedstud00mill 


\section{Progroses Daport}

TEAFIC SFBSD STUDEES

FROERESS REPCRT $\mathrm{NO}_{0} \mathbf{7 2}$

TOa

x. B. Noole, DAroctere

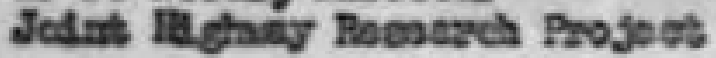

Junt 23, 2961

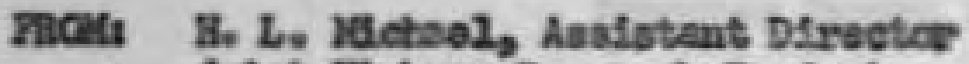

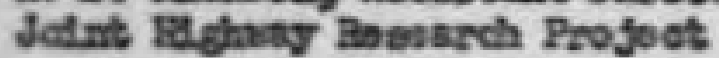

Fla No: 8-3-3

Profoet Ilo: $0-36-100$

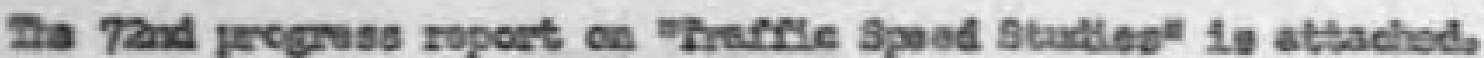

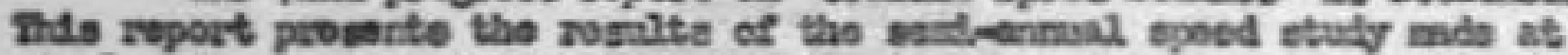

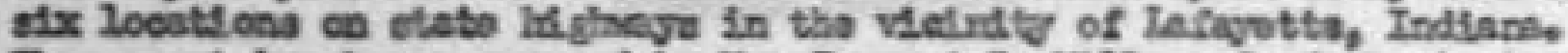

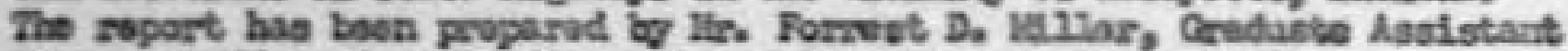

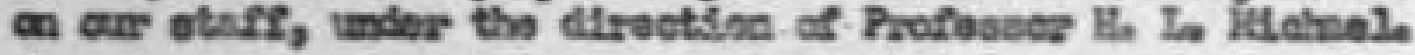

Ins study is anothos in a serlos at thees sas locatlons which

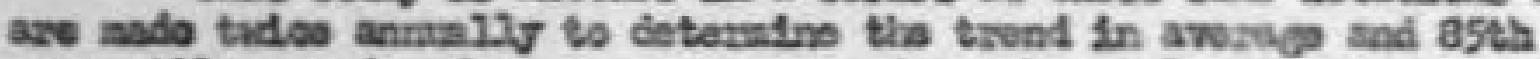
percantslo opoude of passangor cars aol trucles at locatilons whare traffle

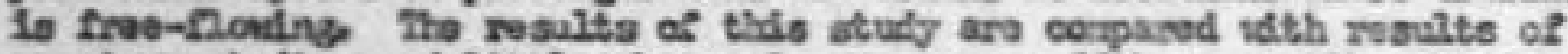

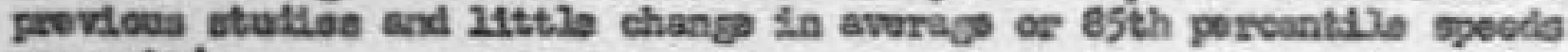
vitas noted.

Tha ropert 10 prosented for tha recard, Coptos udul bo exnt, as usual for thaes atudies, to the Burveu of Publle Roads, the Indiana State Polles, and tho orsloe of Treferic Safotor

Raapoctruly sulanlttod,

Hoes miloel

Harold L, MSchael

Secretary

Imatsene

Attacheant

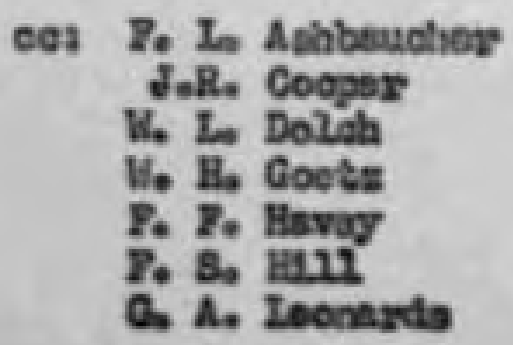

Q. As Hounding ( $16, B_{0}$ Sestt)

J. I. Volsughtin

R. D. valos

R. Z, velus

J. V. Snrtha

J. I. Vating

3. J. Yodne 


\section{Progrose Rapost}

TRATFIC SPESD STUDISS

Procress Aoport llo, 72

$$
\text { by }
$$

Forrost 1811er

Greduate Lsolotant

Jofmt Hifinay Research Project

IIIor $8-3-3$

Projects co-36-30c

Pundus Victraralty

Infagettes Intisna

June 21, 2962 


\section{LIST OF TRBL3S AD YIOURS}

Tebleg

Tablo No.

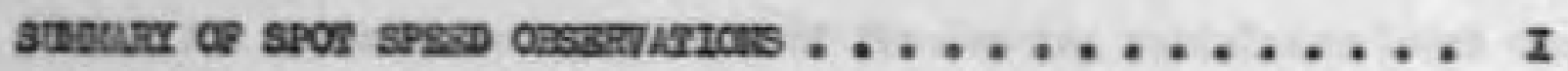

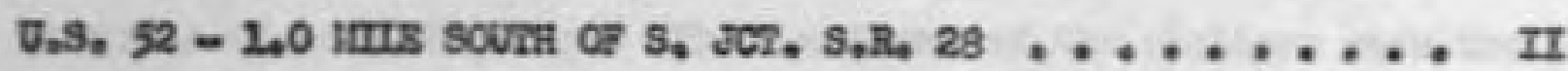

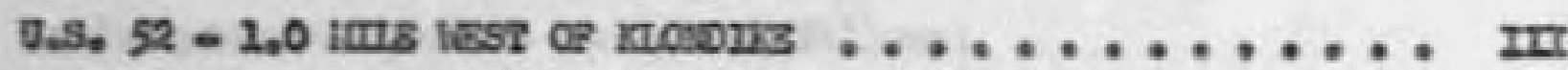

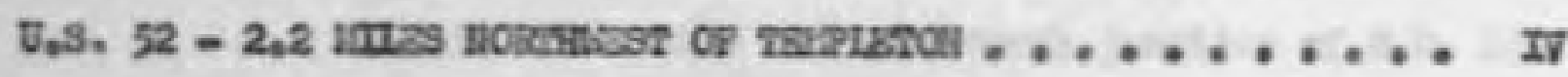

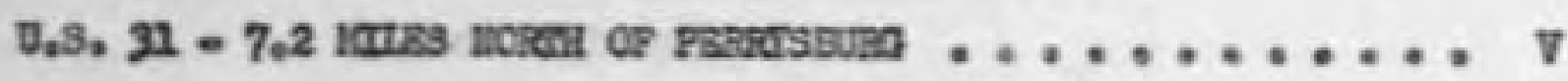

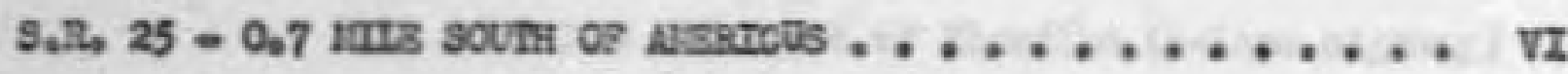

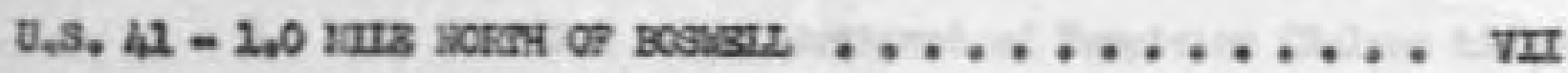

Py/maxas

Brase lloge

FERCSITIS SPESD CURVS

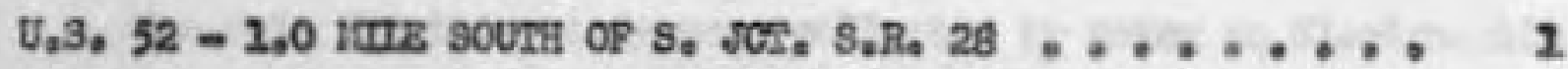

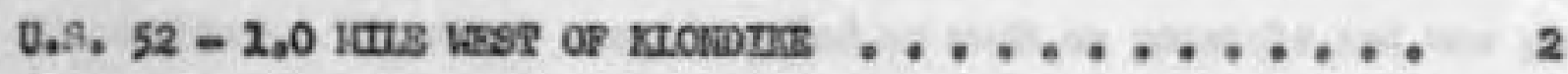

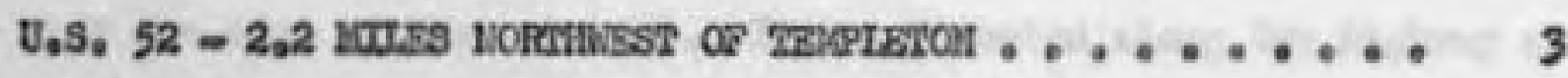

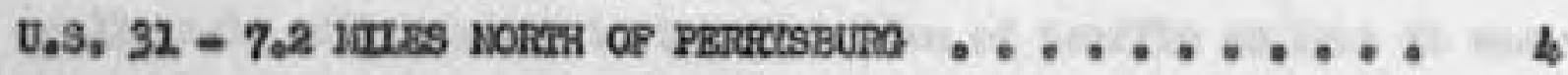

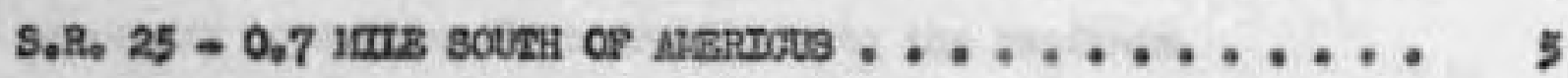

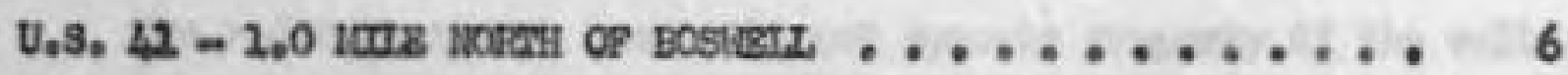

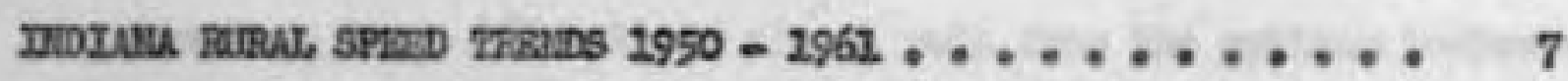

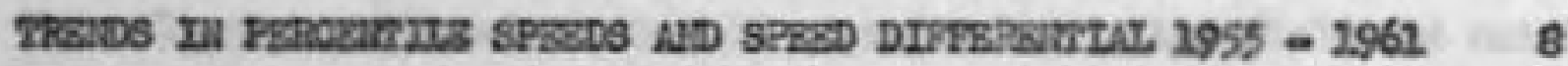


TRATIC SPIED RaPCI No. 72

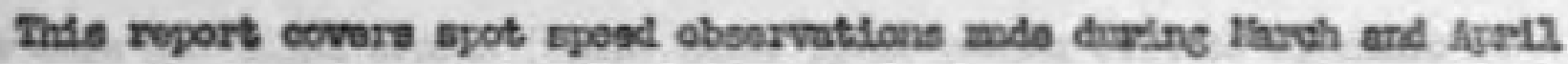

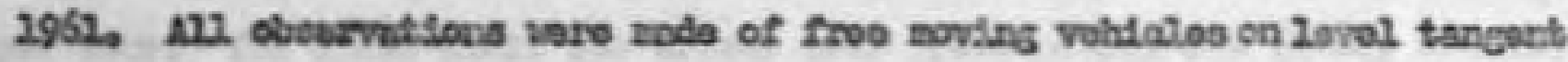
sortions of rural hideeye. The loctitions of the stations vero the sabe es for ptorious otudine and are es follors:

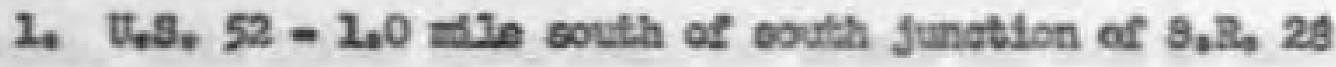
(4-iono hidinas)

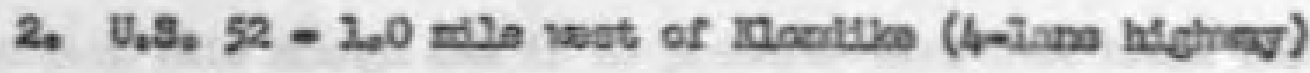

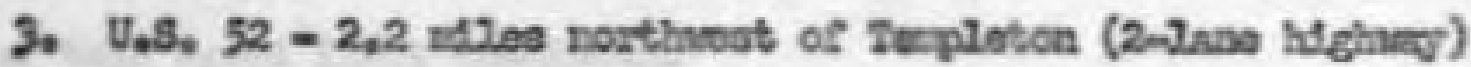

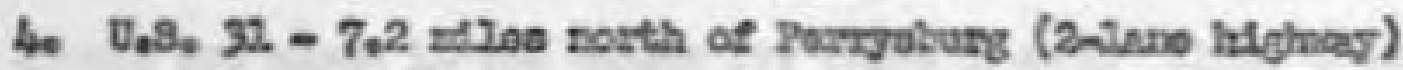

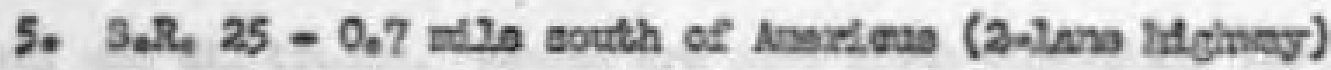

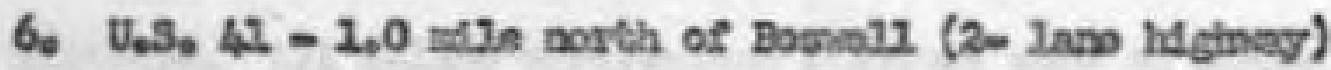

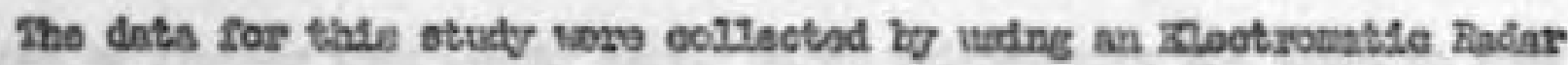
Spood later. The motor weo oonoealed as much as poostblo and vas pleosd noar the edgs of tho pavounnto. It was 6livatod along tho hiftray at a

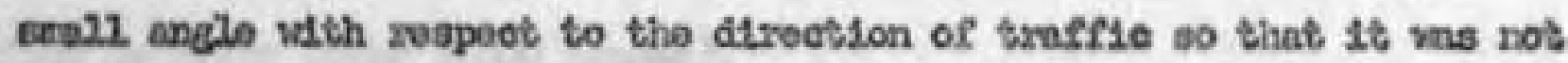
necossary to males ancle oorrections to the 2roadincte.

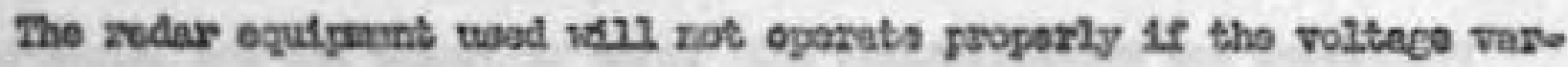

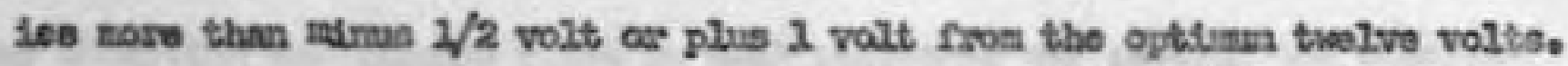

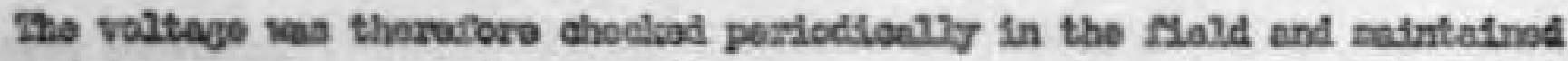

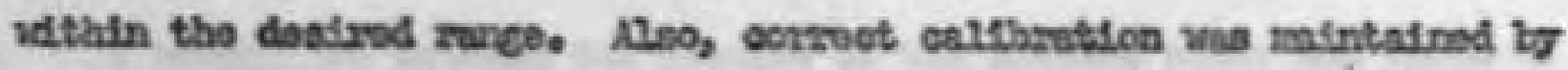
perlodionlly cheolding 1t idth a 60 wlle par hour tuning forlic

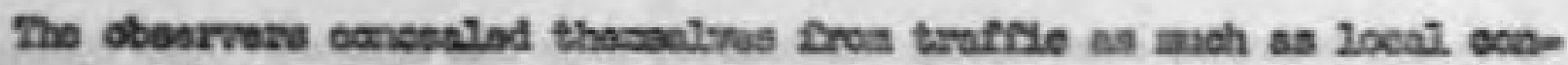

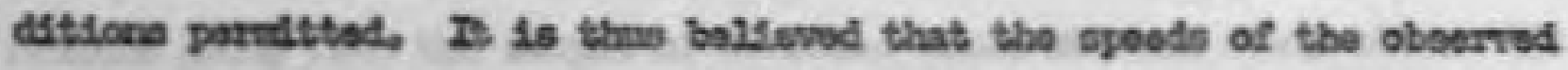
velifeloe verv not influbaced by the obcesvere or the oquifpont. 


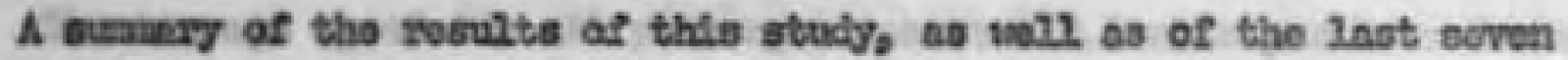

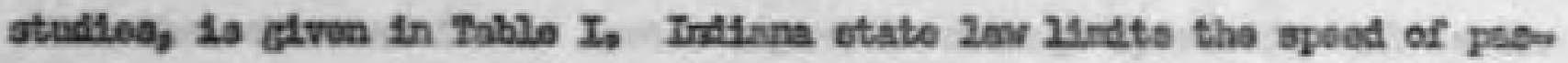

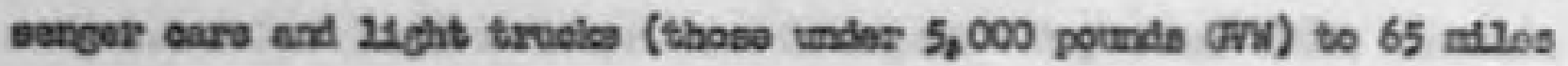
por hour. The opoed liselt fors truales over 5,000 pounds Gin (hnsvg trucles)

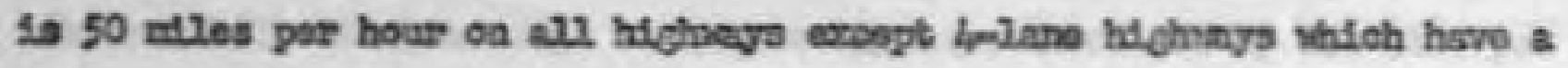

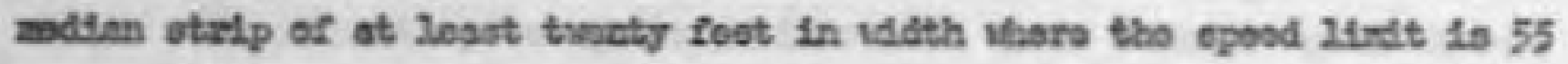

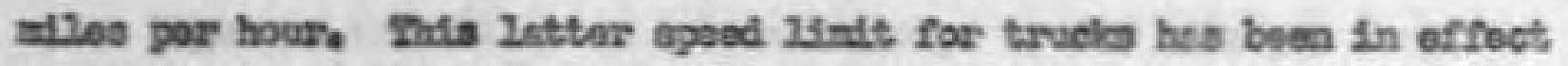

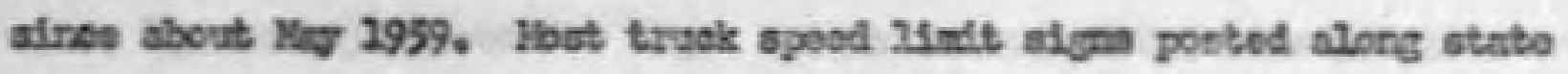
hlohnge rophoct thle ahnge and it is probeble that rost truek drivors are wane of this opoed linit oondstion,

Fruck apeode aro shone in the tables for threo croupst 21 ght truolas,

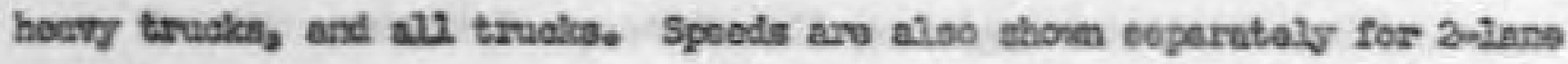

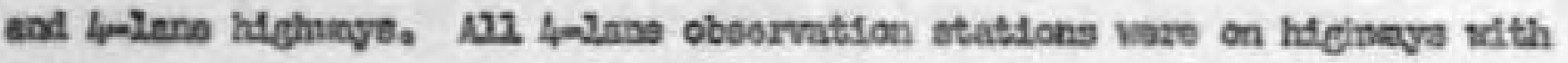

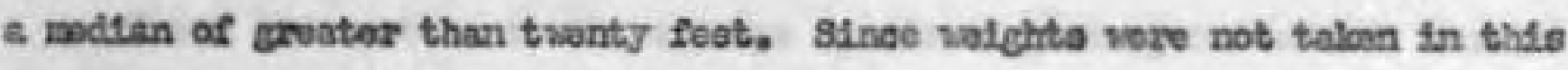

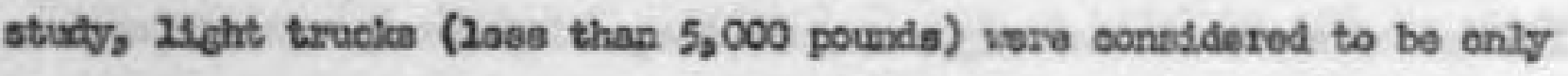

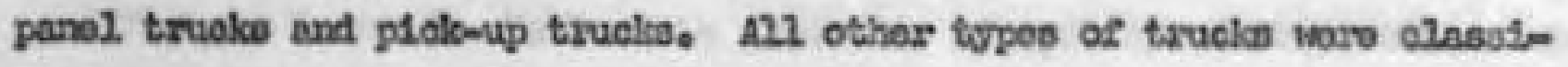
flod as hoavy (over 5,000 pounds).

Tho passongor oer inte wero also alasalfied 1nto threo groups Inctanes out-of-atate, and all pasaenger cers. Ths elaesteloation vas determinad by obverving the licenos plato on each pasacncor ans paesfine the observetion atatsons.

A eocporison botien the results of the prosant sturly and those of tho last provilous stuks (Argaet - Soptanber, 1960) 10 ptoaontod in Fables

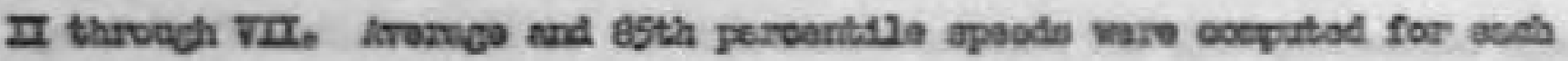
vehlels croup fron the sorple of rohileles talan at each stuty attos wi

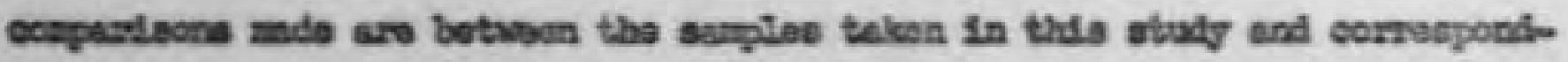
Ing eaploe in Angust - Septentber 1960 , 
The avorace opoed for all passencor oars vas 0.5 milo per hour farter then that obtainod in the last otudy while avarage opoode for ell truake vas 2.1 mas por hour lover then in Auruat - Soptoebor 2960. Indsens pessunger cars had an average opeod on 2-1ene hifhrays 1,0 =110 per hour

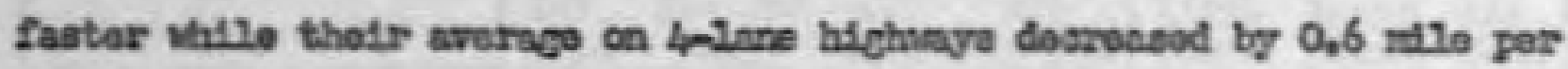
bour. Outrof-etate pessencerr cars ineronsed thols awernge epesd on 2 .

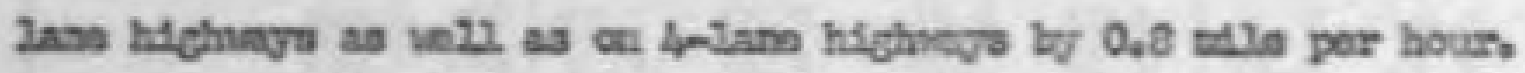

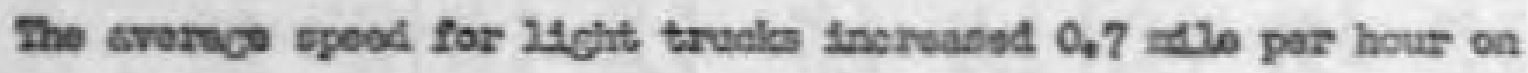

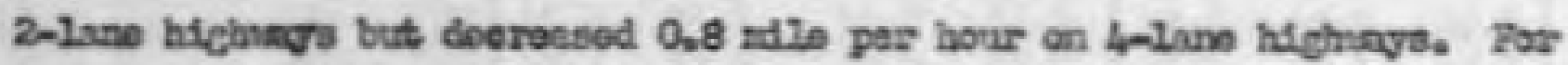

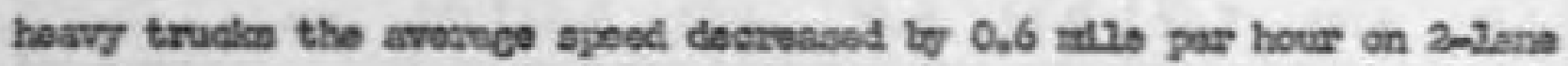

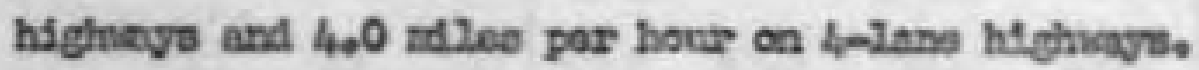

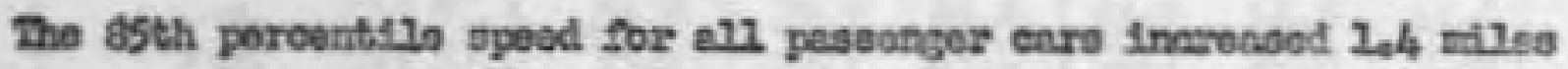
pro hour.

Trond information on the average spoods of possonger oaro and trucks and on the A5th pereent 110 apeod for passoncer aars 13 ahoren in Table I

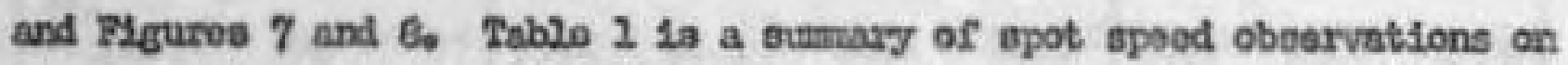
Indlane higlinas for the Inat eight studion (ainos thay 1957). This aun-

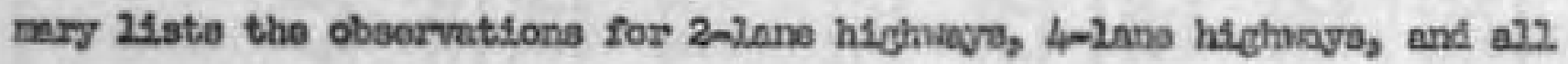
Highnye for both passengor cars and trucles.

Plouro 7 10 a gruph shonding rural opeed trende fron 2950-2962 sor. both pasanger ases and tiruclas.

Figure is is a griph ohoiding trends in porcentilo spoeds and opeed difIexentsal froe 2955-2962 for both peseengar eurs and baary trualas. Tho speod differontinl shoven is the differonos botheon the asth porountilla spesd

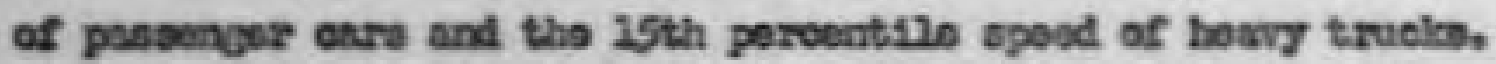




\section{TABLS I}

\section{SURALRY OF SPOT SPEBD OBSERVATION}

CA RDINA HIOHAYYS

(Froe-Moring Vehicles on Level, Tangent Sacticns)

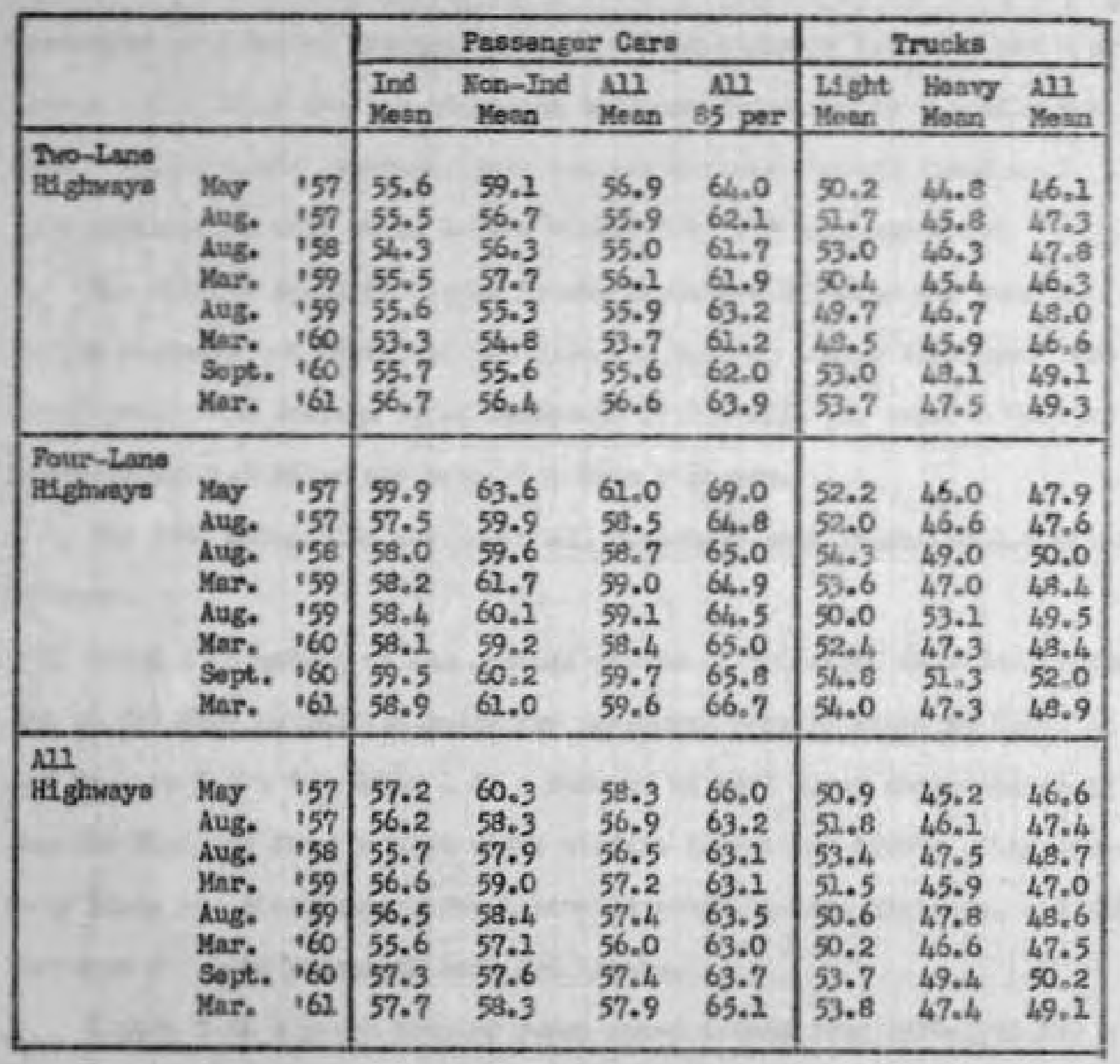




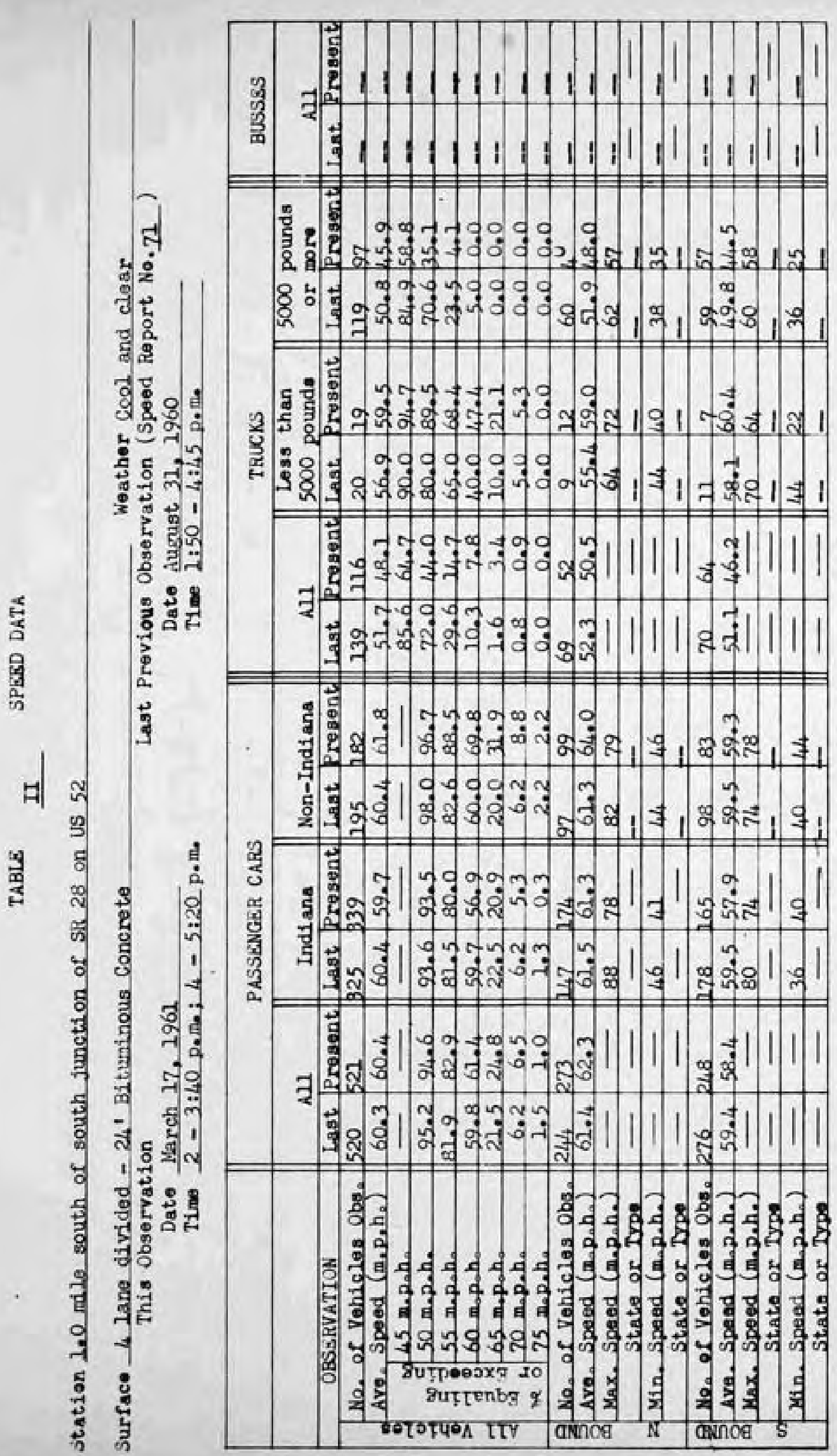




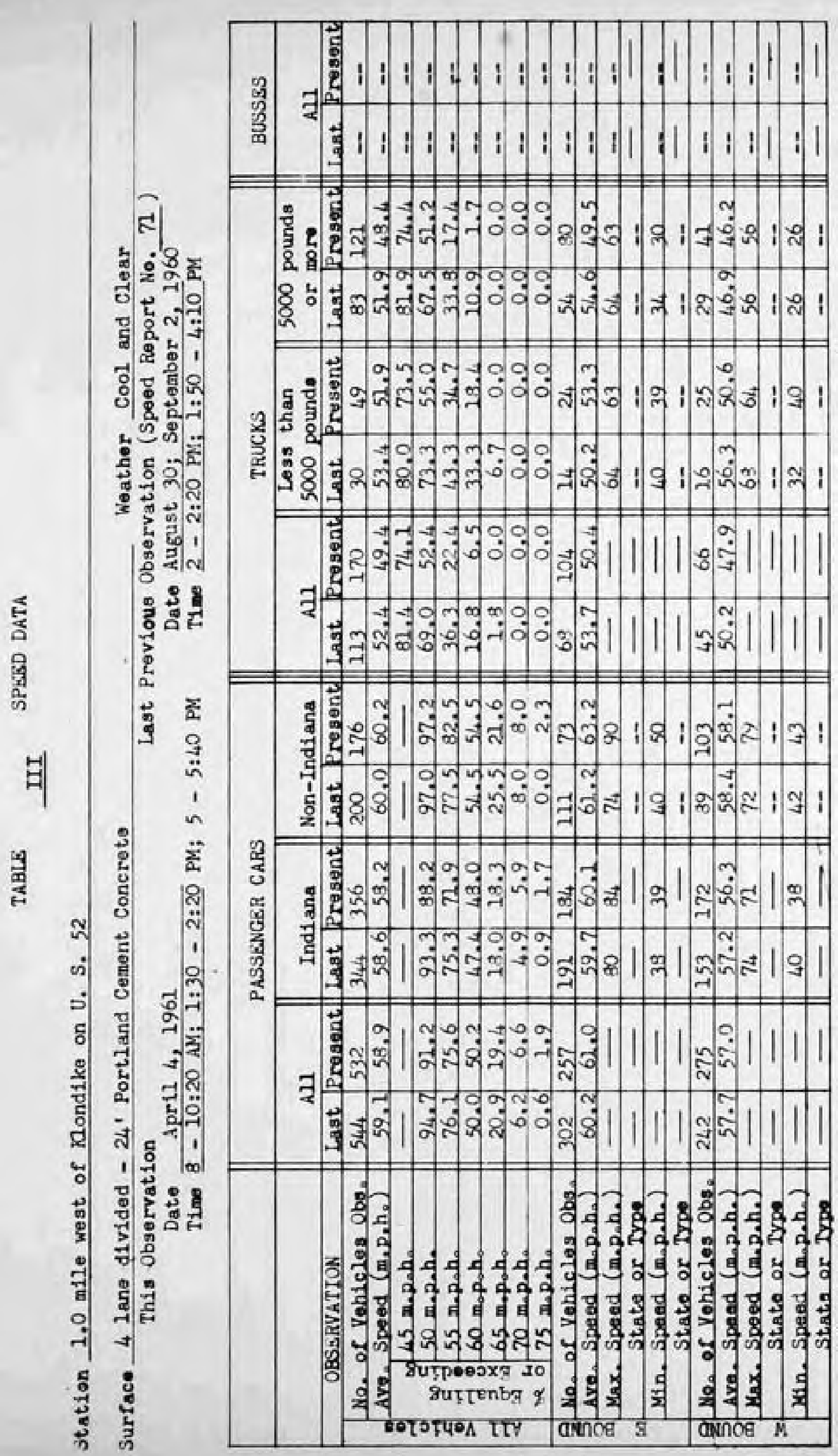




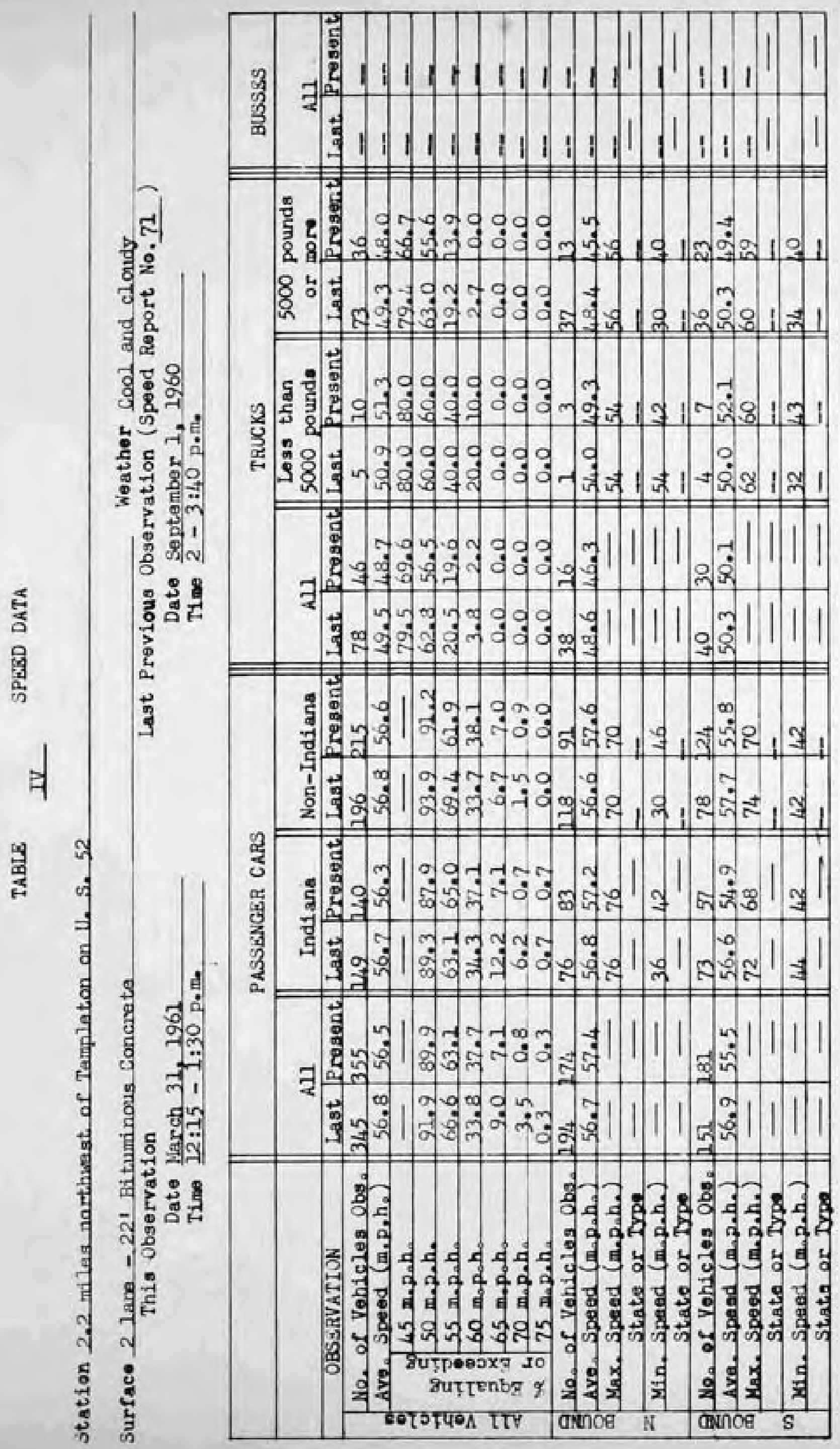




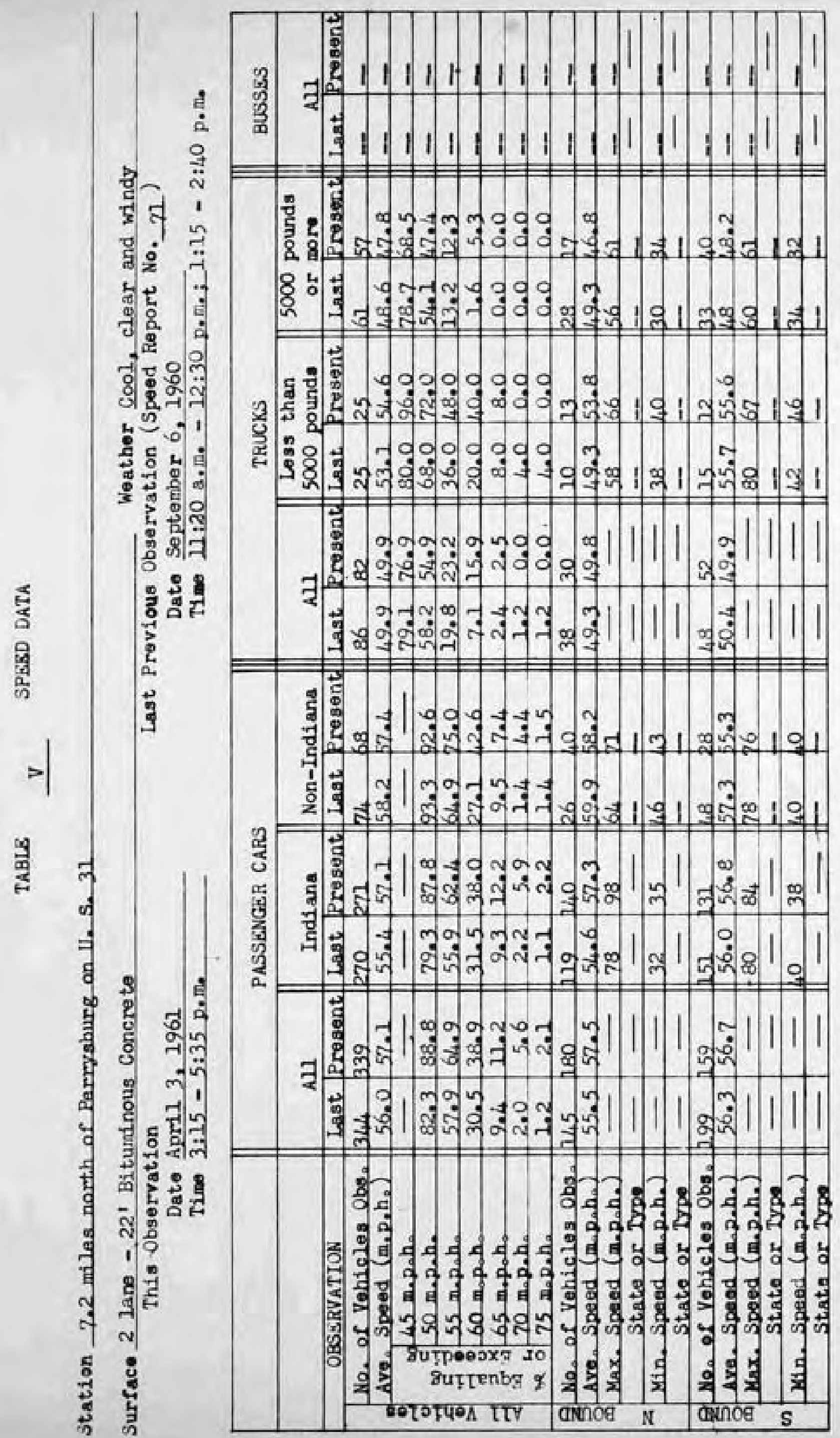




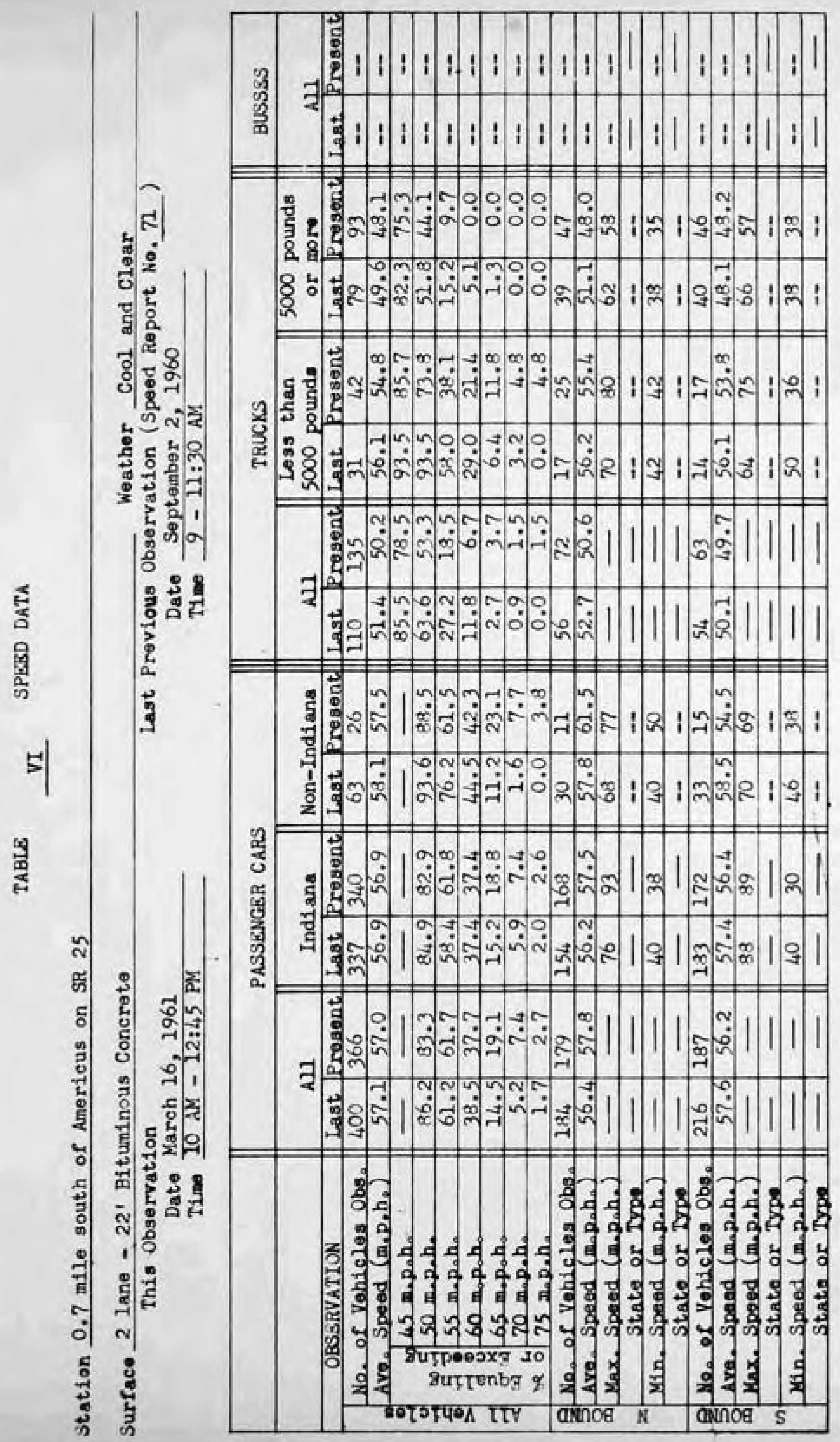




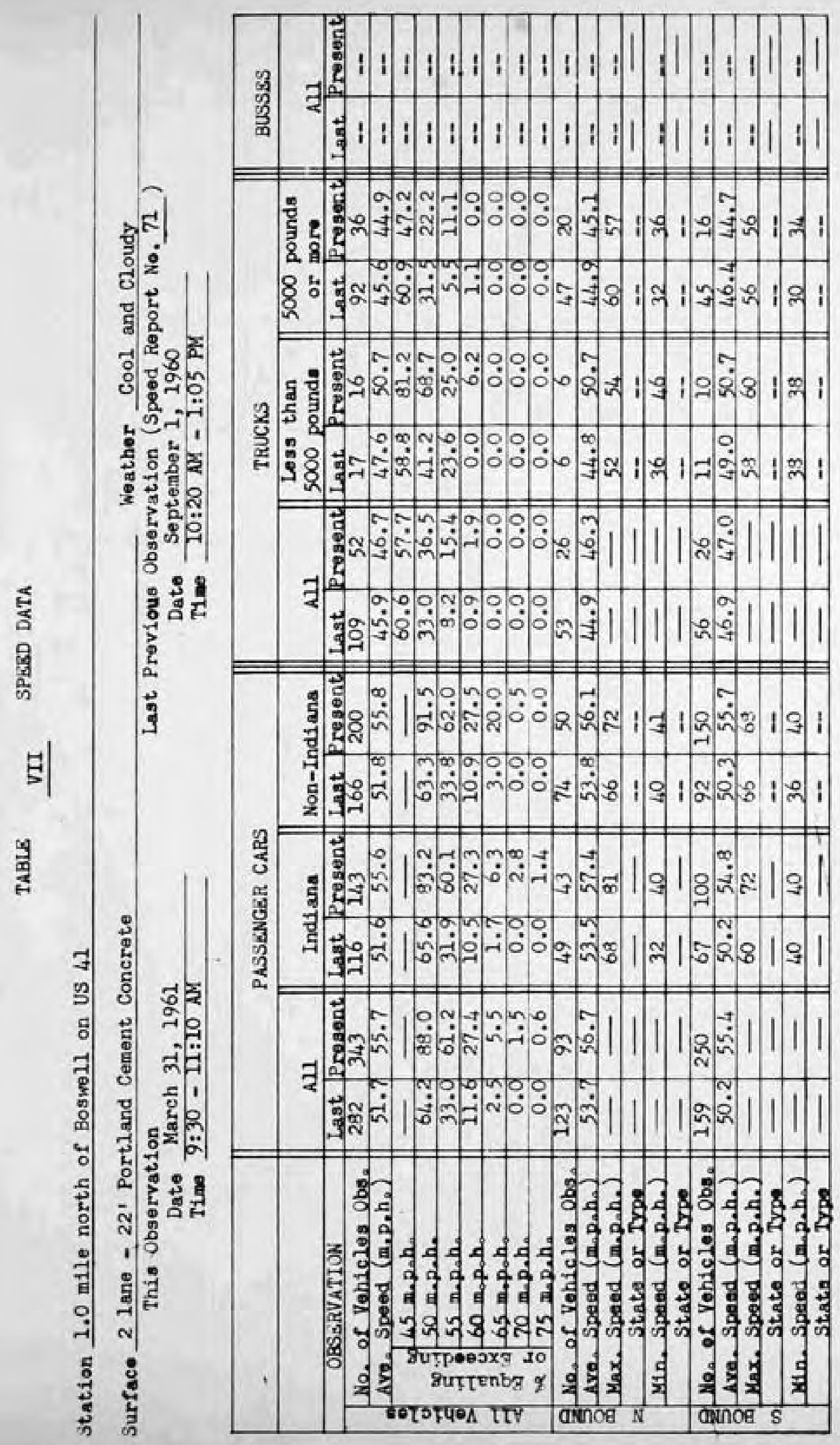




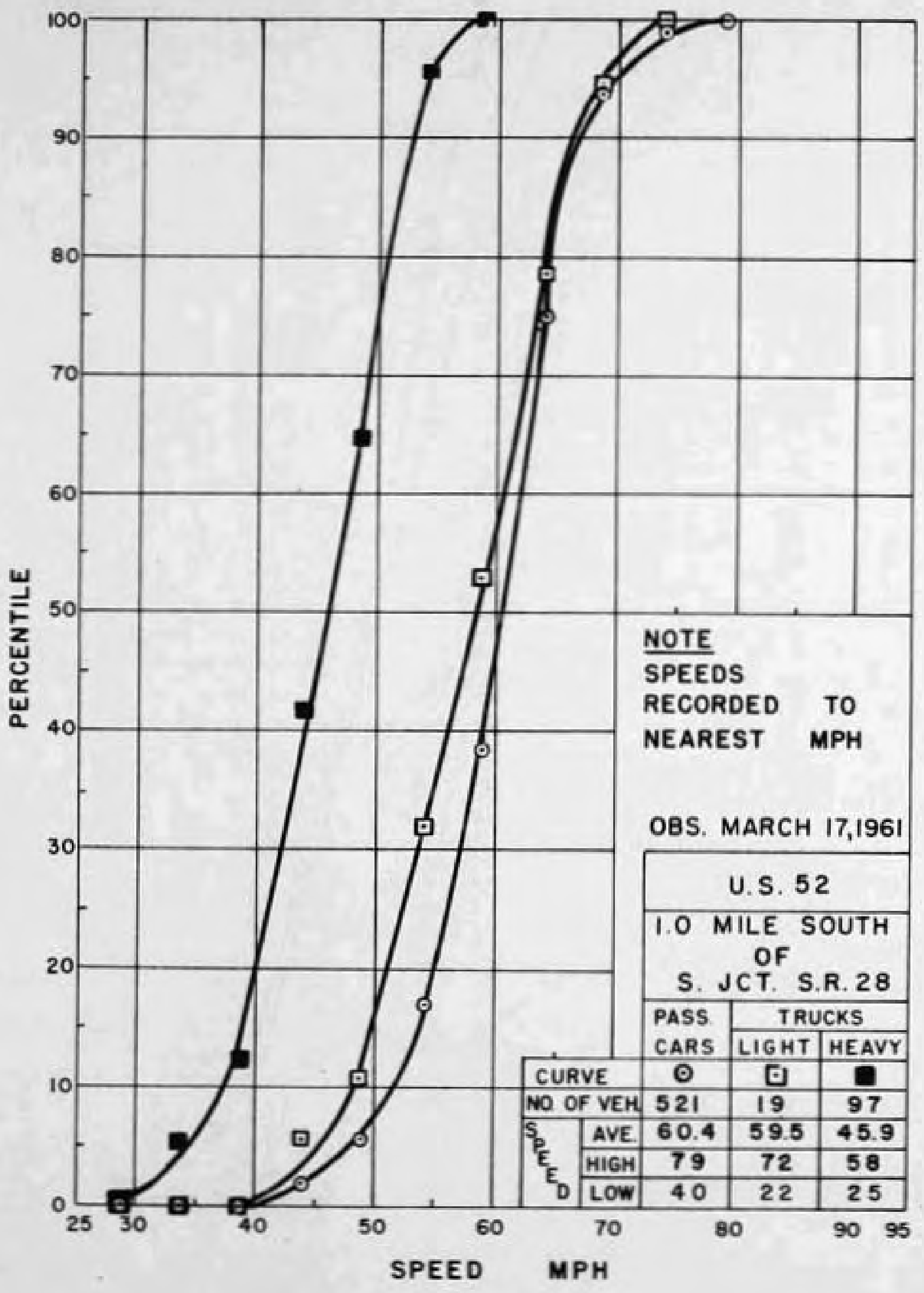

FIGURE I 


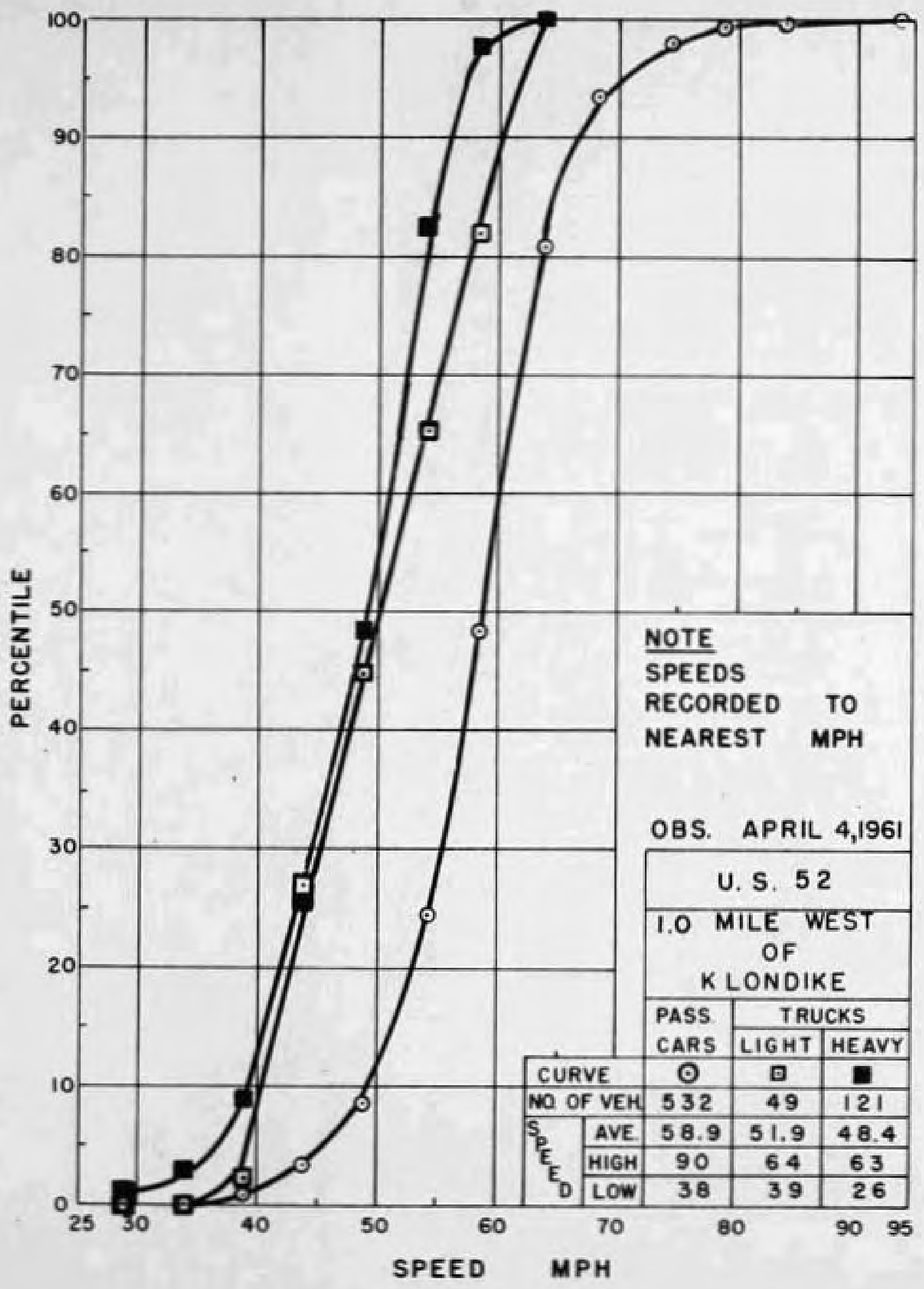

FIGURE 2 


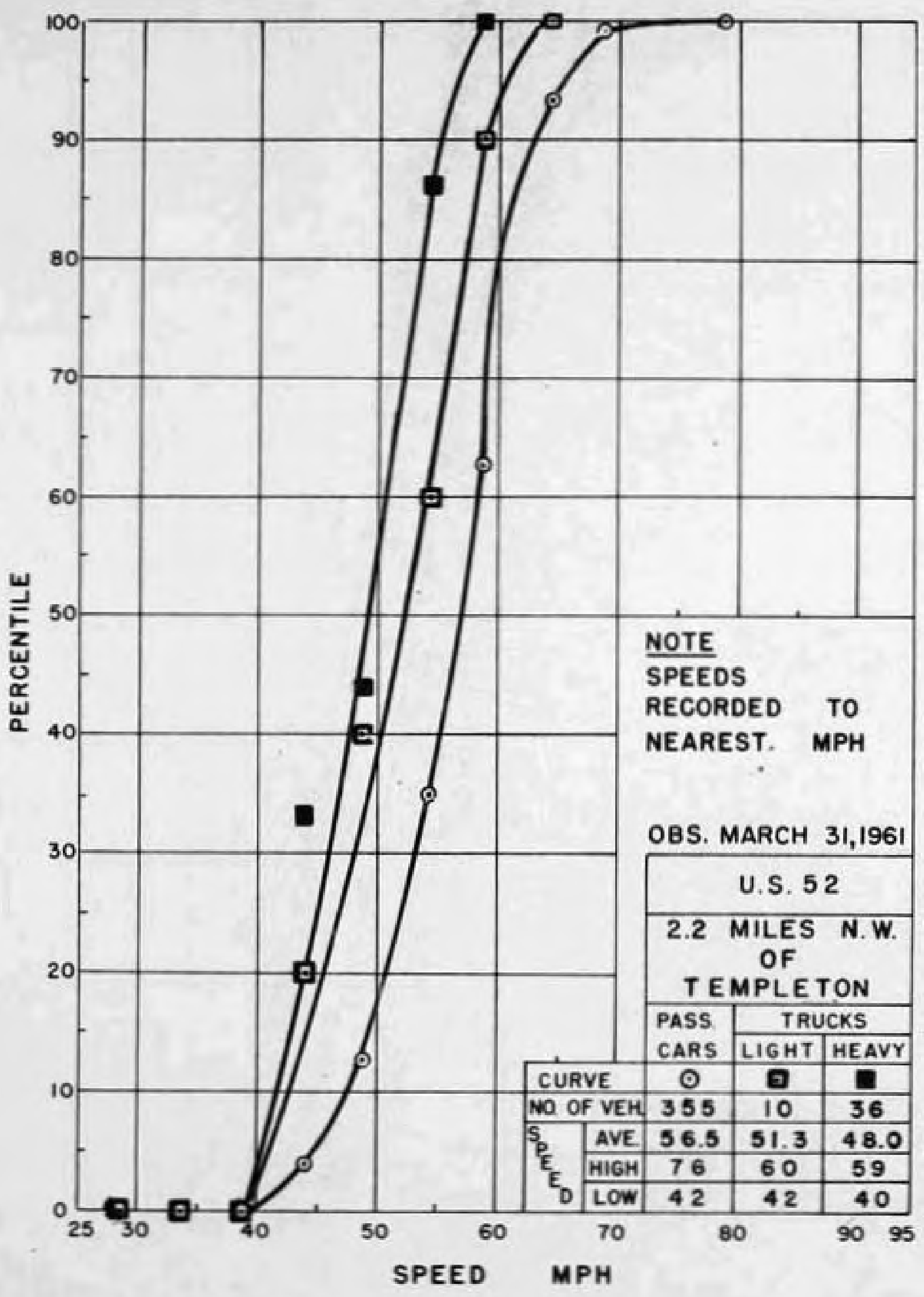

FIGURE 3 


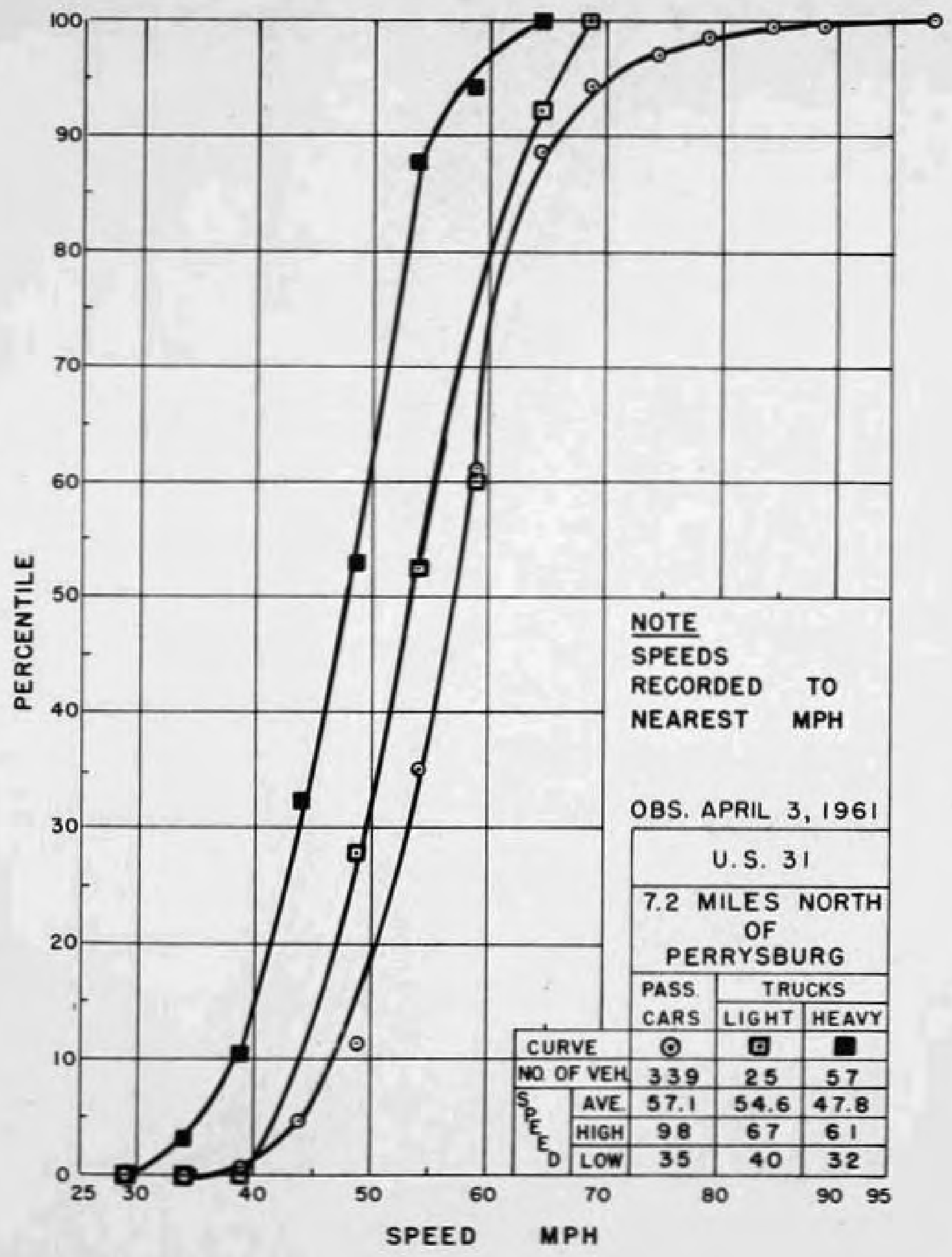

FIGURE 4 


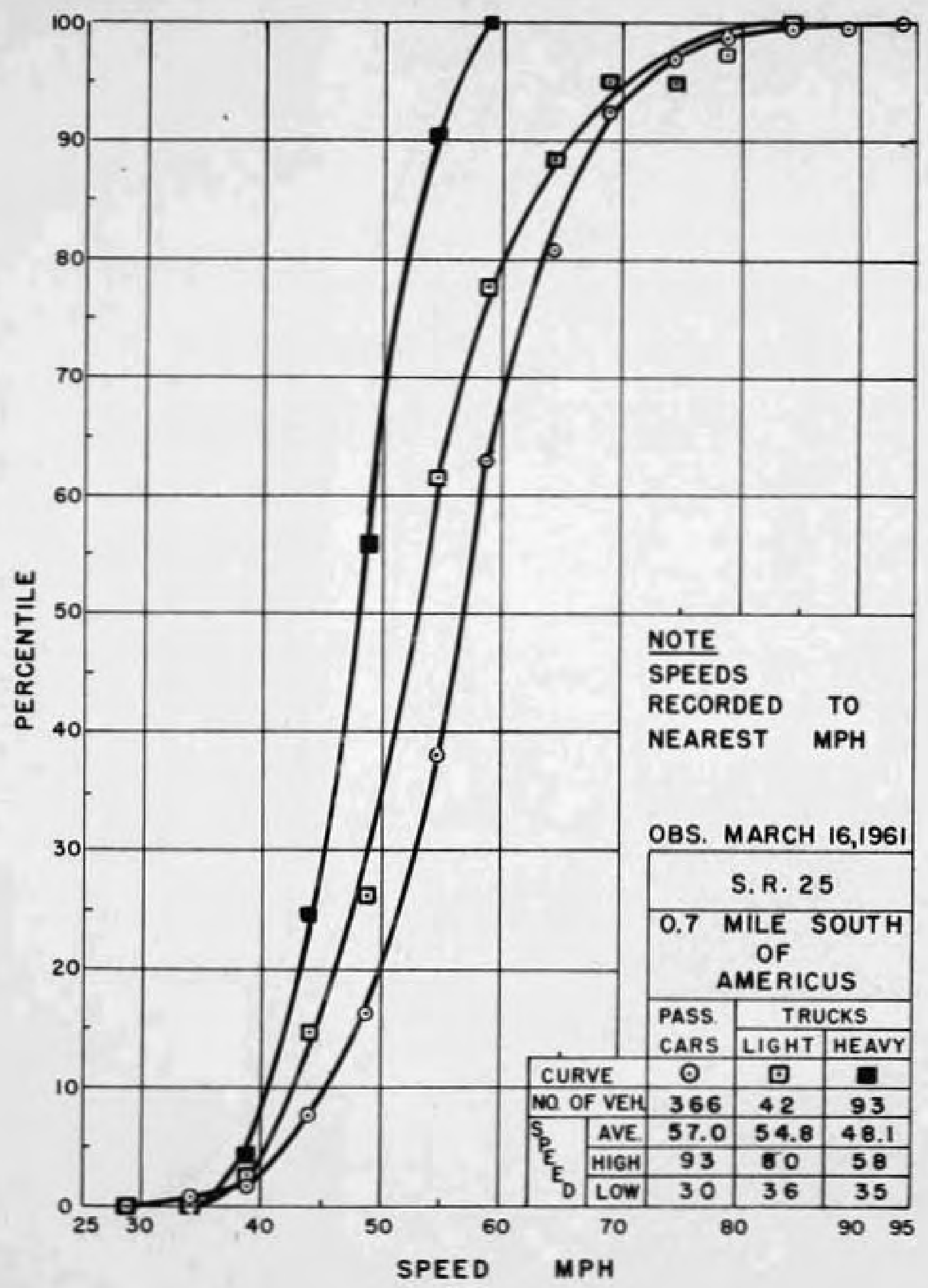

FIGURE 5 


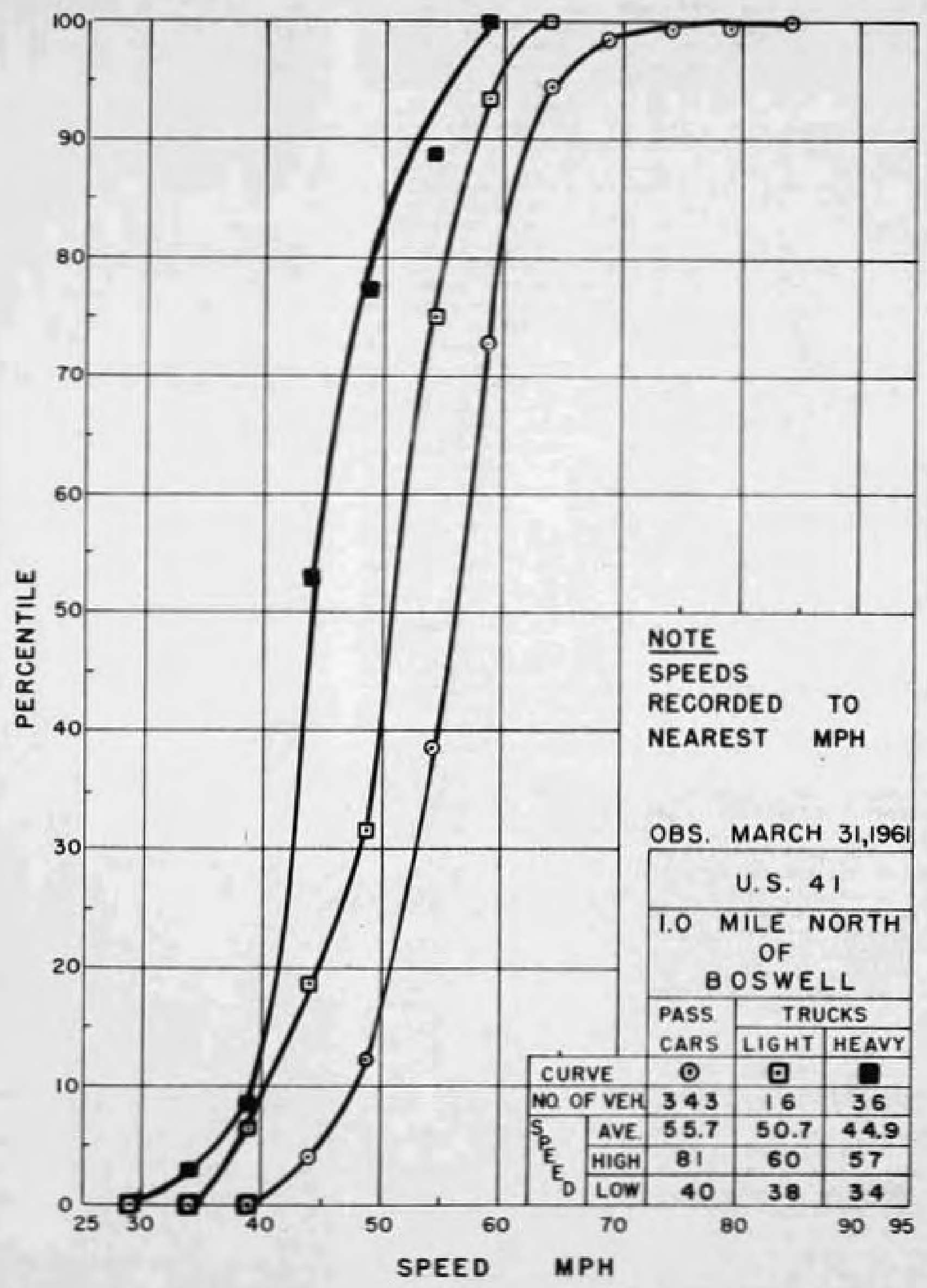

FIGURE 6 


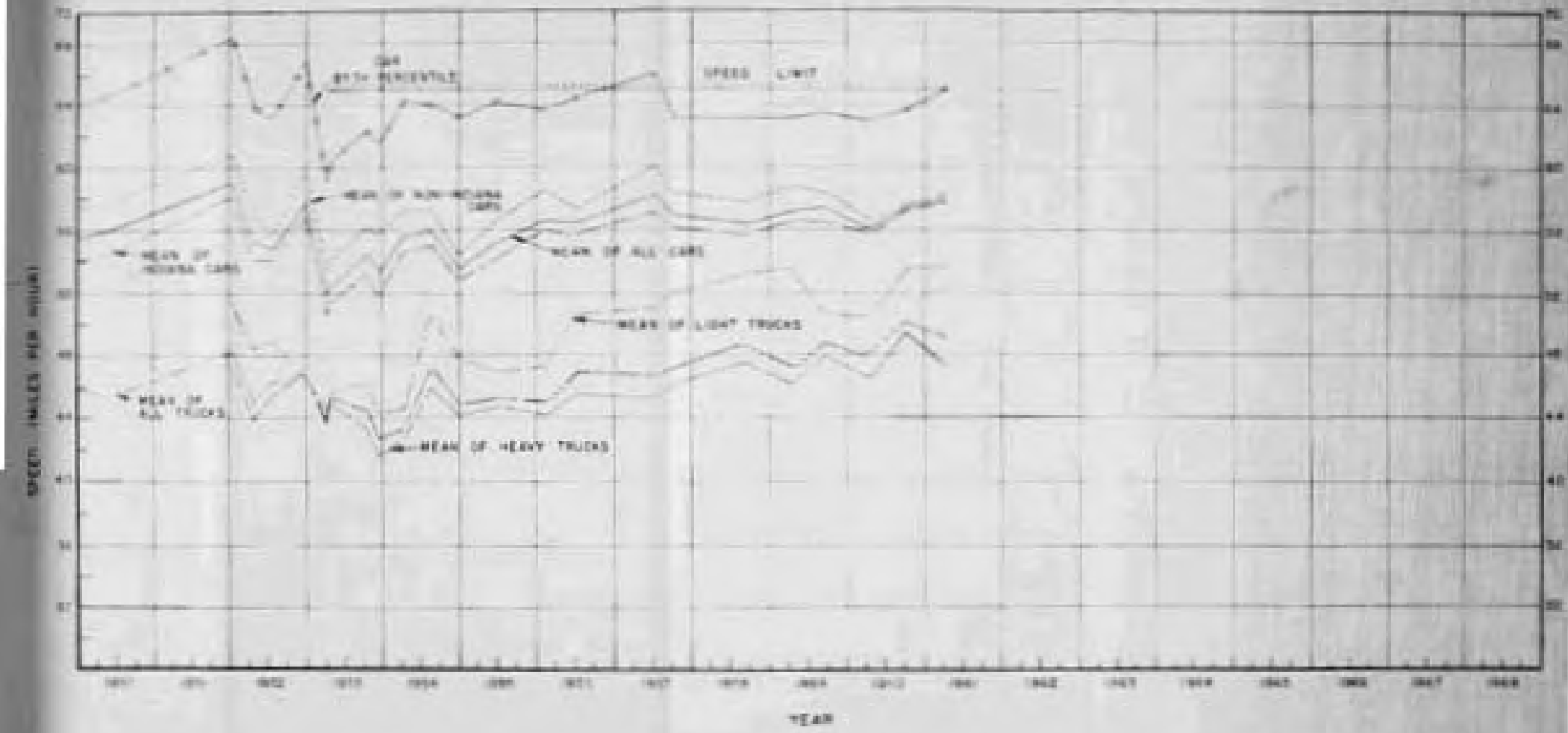


